\title{
EFFECTS OF AGE AND CAPTIVITY ON PLASMA CHEMISTRY VALUES OF THE EGYPTIAN VULTURE ${ }^{1}$
}

\author{
Pablo M. Dobado-Berrios ${ }^{2}$ And José L. TellaA ${ }^{3}$ \\ Department of Applied Biology, Estación Biológica de Doñana, Consejo Superior de Investigaciones \\ Científicas, Avda. de María Luisa s/n, Pabellón del Perú, E-41013 Sevilla, Spain \\ Olga Ceballos \\ Grupo de Estudios Biológicos "Ugarra," Carlos III $194^{\circ}$, E-31002 Pamplona, Spain \\ José A. DONÁZAR ${ }^{4}$ \\ Department of Applied Biology, Estación Biológica de Doñana, Consejo Superior de Investigaciones \\ Científicas, Avda. de Maria Luisa s/n, Pabellón del Perú, E-41013 Sevilla, Spain
}

\begin{abstract}
Despite the interest in blood chemistry for studying ecological and pathological characteristics of birds, sources of variability such as age and captivity are poorly understood, and reference values usually are obtained from adult captive birds. We determined 15 plasma chemical variables for 164 free-living Egyptian Vultures (Neophron percnopterus) of three age groups (nestlings, subadults, and adults), and for 9 captive adults. Free-living subadults and adults exhibited identical plasma chemistry values. Nestlings had significantly higher levels of creatinine, urate, urea, triglycerides, calcium, phosphorus, and alkaline phosphatase (AP) than both free-living subadults and adults, but lower values of glucose and aspartate aminotransferase (AST). Captive adults had significantly higher levels of total protein, albumin, creatinine, urate, cholesterol, calcium, phosphorus, and AST than free-living adults, which we attribute to differences in diet quality and physical activity. We conclude that future studies should consider age as a major source of variability in avian plasma chemistry, and that results obtained from captivity should be used cautiously to interpret plasma chemistry in the study and rehabilitation of wild birds.
\end{abstract}

Key words: age, captivity, Egyptian Vulture, Neophron percnopterus, plasma chemistry, raptors.

\section{INTRODUCTION}

Many studies have attempted to determine normal values for plasma metabolites and enzymes of raptors and other wild bird species, and these data are of ecological, metabolic, taxonomic, and veterinary interest (Lewandowski et al. 1986, Redig 1991, Ferrer 1993). However, wideranging applications of plasma chemistry to the study and management of free-living, often vulnerable, populations of birds are still limited. Reference values are available only for less than $5 \%$ of bird species, and factors affecting variability of plasma biochemistry values are poorly known (Ferrer 1993).

\footnotetext{
${ }^{1}$ Received 21 October 1997. Accepted 22 June 1998.

${ }^{2}$ Current address: Hospital Universitario "Reina Sofía," Unidad de Investigación, Avda. de Menéndez Pidal s/n, E-14004 Córdoba, Spain.

${ }^{3}$ Current address: Department of Biology, University of Saskatchewan, Saskatoon, Saskatchewan, S7N oW0, Canada.

${ }^{4}$ Corresponding author. e-mail: donazar@ebd03.ebd.csic.es
}

More precisely, information on the effects of age on plasma metabolites and enzymes is still scarce and fragmentary. Changes during the nestling period have been reported (Viñuela et al. 1991, Montesinos et al. 1997), but few studies have compared chicks with adults (Puerta et al. 1992, de le Court et al. 1995, Ferrer and Dobado-Berrios, in press) or have documented changes during the life of birds (Dobado-Berrios and Ferrer 1997). Even so, with the sole exception of de le Court et al. (1995), this information has been partially obtained under captivity. Stocks of wild birds kept in farms, research centers, and zoos have been the primary source for establishing plasma reference levels, and these profiles used to establish inferences about wild populations could be biased by factors associated with captivity. Perry et al. (1986) found that captive Canvasbacks (Aythya valisineria) had higher albumin values, but lower cholesterol, alkaline phosphatase (AP), and L-lactate dehydrogenase $(\mathrm{LDH})$ than did free-living subjects, the differences being attributed to increased stress of wild ducks during handling. However, dramatic 
differences between captive and wild birds could be expected in other species, as many metabolic and enzymatic values can be influenced by such factors as activity level and muscle tone (Bell and Freeman 1971, Wolf et al. 1985), diet quality (Lewandowski et al. 1986, Sturkie 1986, Costa et al. 1993), food restriction (Migliorini et al. 1973, Ferrer et al. 1987, García-Rodríguez et al. 1987), health status (Ivins et al. 1986), and presence of environmental toxicants in the diet (Hoffman et al. 1985).

In this paper, we examine the potential effects of age and captivity on plasma chemistry values in the Egyptian Vulture (Neophron percnopterus). This is a Palearctic migrant species whose populations have undergone a fairly general decline in Europe (Donázar 1993). Some conservation projects include captive breeding of individuals obtained from rehabilitation centers for restocking local populations (Terrasse 1990), and the acquisition of plasma chemistry reference values for use in clinical pathology. However, the existing data are based upon only 5 adults (Polo et al. 1992) and 24 subadults and adults (Dell'Omo and Cavallina 1996) held in captivity. Here, we analyze 15 plasma chemistry variables from 173 Egyptian Vultures, including nestlings, subadults, and adult free-living birds, as well as captive adults, and test for differences related to age and captivity.

\section{METHODS}

\section{STUDIED BIRDS}

One hundred and thirty nestling (24-75 days old, mean \pm SD: $57 \pm 10$ days old; $1,892 \pm$ $217 \mathrm{~g}$ ), 13 subadult ( $2-3$ years old; $1,961 \pm 154$ $\mathrm{g}$ ), and 21 adult ( $\geq 4$ years old; $2,017 \pm 132 \mathrm{~g}$ ) Egyptian Vultures were sampled from the Bardenas-Monegros area (NE Spain) during the 1988-1994 breeding seasons, between 5 July and 20 August. Subadults and adults were easily distinguished by differences in plumage coloration (Donázar 1993). The diet of the Egyptian Vulture in the study area was variable, and consisted of livestock carrion (Ovidae and Suidae), mammals (mainly lagomorphs), fish, and birds (mainly galliforms, columbiforms, and passerines) (see Donázar 1993). In addition, nine adult birds $(2,125 \pm 184 \mathrm{~g})$, kept in outdoor enclosures at two zoo sites (Barcelona and Madrid, Spain) or at two raptor centers (Sevilleja de la Jara and Lérida, Spain), were sampled. Although fresh whole rabbit, chicken carcasses, and horsemeat were provided once daily in the early morning, these birds fed at any time of the day (Tella, pers. observ.); thus intervals between blood sampling and their last food ingestion should be more similar than in field conditions. Water was provided ad libitum.

All sampled birds appeared healthy upon visual examination. Sex identification was not made, because male and female Egyptian Vultures are morphologically identical (Cavallo et al. 1997). Furthermore, sex had no influence on plasma chemistry values in a previous study on Egyptian Vultures (Dell'Omo and Cavallina 1996).

\section{SAMPLING PROCEDURE AND PLASMA ANALYSES}

Up to $3 \mathrm{ml}$ of blood per bird were taken from the brachial vein with a heparinized syringe. Samples were collected between $1 \mathrm{hr}$ after dawn and $1 \mathrm{hr}$ before dusk. Blood samples were immediately placed in vials containing lithium heparin and kept on ice. Within $12 \mathrm{hr}$ of drawing, plasma was separated by spinning the blood at $3,000 \mathrm{rpm}$ for $10 \mathrm{~min}$, and stored at $-40^{\circ} \mathrm{C}$ until analysis.

Biochemical analyses were conducted at $\mathrm{Na}$ varra Hospital (Pamplona, Spain) using a computer process-controlled multichannel autoanalyzer (Hitachi 747) and kits supplied by Boehringer-Mannheim Biochemica (Mannheim, Germany). The following 15 chemical variables were determined in each plasma sample (abbreviations and methods indicated in parentheses): total protein (Biuret reaction), albumin (BCG method), bilirubin (DPD method), creatinine (Jaffe-Alkaline Picrate method), urate (Uricase reaction), urea (Urease reaction), cholesterol (CHOD-PAP method), triglycerides (GPO-PAP method), glucose (Hexokinase method), calcium (Cresolphtalein Complexone reaction), phosphorus ( $p$-Phosphomolybdate method), alkaline phosphatase (AP; Nitrophenyl-Phosphate method), aspartate aminotransferase (AST; DGKC technique), alanine aminotransferase (ALT; DGKC technique), and L-lactate dehydrogenase (LDH; SFBC technique).

\section{STATISTICAL ANALYSES}

Linear regression and ANOVA were used when assumptions of normality and homoscedasticity were met, otherwise nonparametric statistics 
were used. The Kruskal-Wallis ANOVA and subsequent multiple range test (Dunn's method) were used to determine significant differences among age groups of free-living birds. The Mann-Whitney $U$-test was used to compare between measurements of free-living and captive adult subjects. Bonferroni corrections were used to adjust $P$-values for the number of tests performed, considering "families" of related variables (i.e., groups of plasma constituents which covaried in our study, see Chandler 1995). Data are expressed as mean $\pm \mathrm{SD}$, and ranges also are provided.

\section{RESULTS}

Data are summarized in Table 1. In some cases, the amount of plasma recovered was insufficient for analyzing all chemical variables. Therefore, sample sizes differed for the different chemistries. Means were obtained by pooling all years and hours of sampling to get adequate sample sizes to make the tests between ages and freeliving vs. captive birds. Similar results were found considering the blood samples collected during 1993, the only year with adequate sample size ( $n=48$ free-living vultures) to test for age effects (results not shown). By using the age group with the largest sample size (nestlings, $n$ $=130$ ), we also examined daily variations in concentrations of plasma constituents. No differences were detected in any of the plasma values when blood samples were grouped into six intervals, 120 -min each (one-way ANOVAs, $P$ $>0.05$ for all plasma chemical variables).

Significant age-related differences in creatinine, urate, urea, triglycerides, calcium, phosphorus, AP, AST, and glucose values were detected (Table 1). Because glucose was significantly correlated with body weight in other studies (González and Hiraldo 1991, Jenni-Eiermann and Jenni 1994), we tested whether body weight was responsible for the age-related trend found in our study: lower concentration in nestlings than in subadults or adults (Table 1). A linear regression of glucose on body weight showed a weak but highly significant relationship $(r=$ $0.28, P<0.001, n=154$ ). The combined effects of age and weight on glucose were then examined by analysis-of-variance with age as a categorical main effect, and weight as a covariate. Body weight and glucose levels showed a significant covariation $\left(F_{1,150}=7.6, P<0.01\right)$, but significant differences among age groups were retained $\left(F_{2,150}=16.9, P<0.001 ; P<\right.$ 0.05 by Student-Newman-Keuls test when comparing either subadult or adult glucose values with nestling glucose values).

Free-living and captive adult vultures differed significantly in their values of total protein, albumin, creatinine, urate, cholesterol, calcium, phosphorus, and AST (Table 1).

\section{DISCUSSION}

\section{REFERENCE VALUES}

Nearly all ranges of plasma metabolites and enzymes for nestling vultures were found to overlap with those described for free-living nestlings of other falconiform species (González and Hiraldo 1991, Redig 1991, Ferrer and Dobado-Berrios, in press). Total protein values for free-living subadult and adult vultures fell within the range of variation described for free-living immature and adult Sharp-shinned Hawks (Accipiter striatus) (Powers et al. 1994), but they were lower than those obtained from wild American Kestrels (Falco sparverius) (Dawson and Bortolotti 1997). As far as we know, no plasma chemistry value other than protein has been previously reported for free-living subadult or adult falconiforms.

Values for captive adult vultures fell within ranges of variation described for other adult falconiforms held in captivity (Ferrer et al. 1987, Redig 1991, Ferrer and Dobado-Berrios, in press). However, differences were seen in eight (creatinine, urate, triglycerides, phosphorus, AP, AST, ALT, and LDH) of the 14 available plasma values when compared with previous results from captive Egyptian Vultures (Polo et al. 1992, Dell'Omo and Cavallina 1996). Some of these differences could be related to the different conditions of captivity between studies, such as diet and physical activity.

\section{AGE-RELATED CHANGES}

Age influenced a number of plasma chemistries in the Egyptian Vulture: subadults and adults exhibited similar plasma chemistry values, which differed, however, from nestlings. This agrees with most previous studies conducted with wild and captive subadult and adult birds (Polo et al. 1994, Powers et al. 1994, Ferrer and DobadoBerrios, in press). However, Dell'Omo and Cavallina (1996) found differences in creatinine and cholesterol between subadult and adult captive Egyptian Vultures. We cannot explain this dif- 
TABLE 1. Plasma chemistry values (mean \pm SD [range], sample size) of the Egyptian Vulture, Neophron percnopterus.

\begin{tabular}{|c|c|c|c|c|c|c|}
\hline \multirow[b]{3}{*}{ Variable (SI units) } & \multicolumn{6}{|c|}{ Free-living birds } \\
\hline & \multicolumn{3}{|c|}{ Nestlings } & \multicolumn{3}{|c|}{ Subadults } \\
\hline & $\overline{\mathrm{x}} \pm \mathrm{SD}$ & Range & $n$ & $\overline{\mathrm{x}} \pm \mathrm{SD}$ & Range & $n$ \\
\hline Total protein $\left(\mathrm{g} \mathrm{L}^{-1}\right)$ & $29 \pm 4$ & $(21-40)$ & 130 & $30 \pm 4$ & $(25-35)$ & 13 \\
\hline Albumin $\left(\mathrm{g} \mathrm{L}^{-1}\right)$ & $12 \pm 1$ & $(10-16)$ & 116 & $11 \pm 1$ & $(9-13)$ & 13 \\
\hline Bilirubin $\left(\mu \mathrm{mol} \mathrm{\textrm {L } ^ { - 1 } )}\right.$ & $1.7 \pm 1.7$ & $(0.0-17.0)$ & 130 & $1.7 \pm 0.0$ & $(0.0-1.7)$ & 13 \\
\hline Creatinine $\left(\mu \mathrm{mol} \mathrm{L}^{-1}\right)$ & $30.1 \pm 12.4 \mathrm{~A}$ & $(17.7-123.8)$ & 129 & $22.1 \pm 4.4 \mathrm{~B}$ & $(17.7-26.5)$ & 13 \\
\hline Urate $(\mu \mathrm{mol} \mathrm{L}-1)$ & $529.4 \pm 232.0 \mathrm{~A}$ & $(113.0-1,094.4)$ & 128 & $160.6 \pm 47.6 \mathrm{~B}$ & $(101.1-232.0)$ & 13 \\
\hline Urea $\left(\mathrm{mmol} \mathrm{L}^{-1}\right)$ & $1.5 \pm 0.7 \mathrm{~A}$ & $(0.3-2.8)$ & 127 & $0.7 \pm 0.3 \mathrm{~B}$ & $(0.3-1.7)$ & 13 \\
\hline Cholesterol (mmol L-1) & $6.0 \pm 1.1$ & $(3.9-8.8)$ & 128 & $6.2 \pm 0.8$ & $(4.9-7.8)$ & 13 \\
\hline Triglycerides (mg dL ${ }^{-1}$ ) & $138 \pm 35 \mathrm{~A}$ & $(57-239)$ & 107 & $88 \pm 9 \mathrm{~B}$ & $(75-103)$ & 12 \\
\hline Glucose $\left(\mathrm{mmol} \mathrm{L}^{-1}\right)$ & $12.5 \pm 1.8 \mathrm{~A}$ & $(7.8-16.9)$ & 127 & $14.8 \pm 1.6 \mathrm{~B}$ & $(11.3-17.1)$ & 12 \\
\hline Calcium $\left(\mathrm{mmol} \mathrm{L}^{-1}\right)$ & $2.3 \pm 0.4 \mathrm{~A}$ & $(1.2-2.9)$ & 126 & $1.6 \pm 0.3 \mathrm{~B}$ & $(1.4-2.5)$ & 13 \\
\hline Phosphorus (mmol L-1) & $2.0 \pm 0.5 \mathrm{~A}$ & $(0.9-3.1)$ & 123 & $0.6 \pm 0.3 \mathrm{~B}$ & $(0.4-1.2)$ & 9 \\
\hline $\mathrm{AP}\left(\mathrm{IU} \mathrm{L}^{-1}\right)$ & $1,172 \pm 408 \mathrm{~A}$ & $(462-2,331)$ & 127 & $63 \pm 30 \mathrm{~B}$ & $(12-141)$ & 13 \\
\hline $\operatorname{AST}\left(\mathrm{U} \mathrm{L}^{-1}\right)$ & $57 \pm 17 \mathrm{~A}$ & $(26-107)$ & 126 & $70 \pm 8 \mathrm{~B}$ & $(57-83)$ & 11 \\
\hline $\operatorname{ALT}\left(\mathrm{U} \mathrm{L}^{-1}\right)$ & $3 \pm 1$ & $(0-6)$ & 44 & 3 & & 1 \\
\hline $\mathrm{LDH}\left(\mathrm{U} \mathrm{L}^{-1}\right)$ & $800 \pm 119$ & $(595-1,031)$ & 35 & 750 & & 1 \\
\hline
\end{tabular}

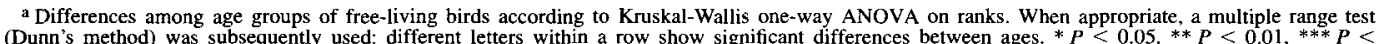
(Dunn's method) was subseque
$0.001, \mathrm{~ns}=$ nonsignificant.

$\mathrm{b}$ Differences between free-living and captive adults according to Mann-Whitney rank sum test.

$c$ Lack of statistically significant differences after using Bonferroni-type procedures.

AP: alkaline phosphatase, AST: aspartate aminotransferase, ALT: alanine aminotransferase, LDH: L-lactate dehydrogenase.

ference with our study, although their results may have been influenced by smaller sample sizes.

Total protein concentration appeared to be lower in nestlings as compared with adults, which is the trend in other wild bird species (Costa et al. 1993, de le Court et al. 1995). However, this effect may be doubtful in the Egyptian Vulture. Statistical significance was lacking after performing the Bonferroni-type adjustment. In addition, age-related changes in albumin values were not found.

Increased urate levels in nestlings compared to adults also have been found in other species (Puerta et al. 1992, Costa et al. 1993, de le Court et al. 1995). In White Spoonbills (Platalea leucorodia), this difference was attributed to a larger daily protein intake of nestlings (de le Court et al. 1995). There is no evidence for this possibility in the Egyptian Vulture. Costa et al. (1993) suggested an immature renal function in captive Emu (Dromaius novaehollandiae) chicks caused an impaired clearance of nitrogen waste products. Our results agree with such an explanation because, aside from urate, urea and creatinine values were higher in nestling vultures. Alternatively, these elevated levels in nestlings may reflect increased protein turnover as part of the rapid growth process.
Cholesterol values were not affected by age in free-living Egyptian Vultures. Similar findings were reported for other bird species (Puerta et al. 1990, 1992, Polo et al. 1994, de le Court et al. 1995; but see Gavett and Wakeley 1986), when the youngest subjects sampled were over 10 days old. High levels of cholesterol after hatching may occur in precocial birds with large amounts of fat in the yolk sac (Sturkie 1986, Costa et al. 1993).

Triglycerides are major energy substrates that birds can utilize directly or store at a number of intraperitoneal and subcutaneous sites (JenniEiermann and Jenni 1994). Age did not modify triglyceride level in captive Flamingos (Phoenicopterus ruber) (Puerta et al. 1992). However, higher triglyceride levels in nestling vultures agree with previous observations in free-living spoonbills (de le Court et al. 1995), and is consistent with a loss of body mass initiated with the fledgling period and with increased fledgling and other physical activities (Ceballos and Donázar 1990, Donázar and Ceballos 1990).

Glucose values were significantly higher in subadult and adult than nestling Egyptian Vultures, even when the effects of weight were controlled for (see also González and Hiraldo 1991, Jenni-Eiermann and Jenni 1994). This age-related trend suggests a greater removal of plasma 
TABLE 1. Extended.

\begin{tabular}{|c|c|c|c|c|c|c|c|}
\hline \multicolumn{4}{|c|}{ Free-living birds } & \multicolumn{3}{|c|}{ Captive birds } & \multirow[b]{3}{*}{$P^{\mathrm{b}}$} \\
\hline \multicolumn{3}{|c|}{ Adults } & \multirow[b]{2}{*}{$p^{a}$} & \multicolumn{3}{|c|}{ Adults } & \\
\hline$\overline{\bar{x}}$ & Range & $n$ & & $\overline{\mathrm{x}} \pm \mathrm{SD}$ & Range & $n$ & \\
\hline $32 \pm 4$ & $(25-37)$ & 20 & $*_{\mathrm{c}}$ & $43 \pm 7$ & $(31-52)$ & 8 & $* * *$ \\
\hline $12 \pm 2$ & $(8-15)$ & 20 & ns & $15 \pm 1$ & $(15-16)$ & 5 & $* *$ \\
\hline $1.7 \pm 1.7$ & $(0.0-5.1)$ & 20 & ns & $1.7 \pm 1.7$ & $(0.0-3.4)$ & 8 & $\mathrm{~ns}$ \\
\hline $23.9 \pm 5.3 \mathrm{~B}$ & $(17.7-35.4)$ & 20 & ** & $30.9 \pm 4.4$ & $(26.5-35.4)$ & 8 & $* *$ \\
\hline $237.9 \pm 130.9 \mathrm{~B}$ & $(71.4-612.6)$ & 21 & $* * *$ & $565.1 \pm 273.6$ & $(273.6-921.9)$ & 9 & $* * *$ \\
\hline $1.0 \pm 0.5 \mathrm{~B}$ & $(0.3-2.0)$ & 21 & $* * *$ & $1.3 \pm 0.7$ & $(0.3-2.2)$ & 9 & ns \\
\hline $6.7 \pm 1.0$ & $(5.2-8.3)$ & 20 & ns & $8.6 \pm 0.6$ & $(7.7-9.4)$ & 7 & ** \\
\hline $110 \pm 27 \mathrm{~B}$ & $(72-158)$ & 15 & $* * *$ & $108 \pm 50$ & $(44-186)$ & 8 & $\mathrm{~ns}$ \\
\hline $15.0 \pm 2.0 \mathrm{~B}$ & $(10.2-17.4)$ & 16 & $* * *$ & $15.7 \pm 1.6$ & $(14.0-18.0)$ & 8 & $\mathrm{~ns}$ \\
\hline $1.9 \pm 0.5 \mathrm{~B}$ & $(1.2-2.6)$ & 20 & $* * *$ & $2.8 \pm 0.3$ & $(2.5-3.1)$ & 7 & $* * *$ \\
\hline $0.8 \pm 0.6 \mathrm{~B}$ & $(0.4-2.4)$ & 18 & $* * *$ & $1.2 \pm 0.3$ & $(0.8-1.7)$ & 8 & $*$ \\
\hline $59 \pm 30 \mathrm{~B}$ & $(0-120)$ & 21 & $* * *$ & $83 \pm 36$ & $(40-142)$ & 8 & ns \\
\hline $75 \pm 13 \mathrm{~B}$ & $(56-99)$ & 17 & $* * *$ & $128 \pm 52$ & $(82-226)$ & 8 & $* * *$ \\
\hline $4 \pm 2$ & $(1-6)$ & 8 & $\mathrm{~ns}$ & $16 \pm 12$ & $(7-30)$ & 3 & $* \mathrm{c}$ \\
\hline $801 \pm 74$ & $(728-890)$ & 5 & ns & $628 \pm 105$ & $(554-702)$ & 2 & ns \\
\hline
\end{tabular}

glucose in growing chicks or a greater supply of plasma glucose in both subadults and adults. The latter hypothesis is supported by the high gluconeogenic ability described in adult Black Vultures (Coragyps atratus) (Migliorini et al. 1973). Although there is no information on this pathway for nestlings, changes with age in activity of gluconeogenic enzymes should not be unexpected (Bell and Freeman 1971).

High levels of AP in Egyptian Vulture nestlings is in agreement with previous observations in other bird species (Puerta et al. 1992, Costa et al. 1993, de le Court et al. 1995) and may reflect the stage of maximum somatic growth and osteoblastic activity (Viñuela et al. 1991, Dobado-Berrios and Ferrer 1997). Calcium and phosphorus values were higher in nestling than in adult Egyptian Vultures, as was the case in free-living spooonbills (de le Court et al. 1995). Farmed Emus ranging from 1 week to 12-18 months old showed constant values (Costa et al. 1993).

LDH was unaltered with age, as occurred in captive Flamingos (Puerta et al. 1992). AST activity was lower in Egyptian Vulture chicks, and ALT was not affected by age. Flamingos showed unchanged AST and increased ALT activity with age (Puerta et al. 1992), and farmed Emus exhibited higher AST values in chicks 8 weeks old or less as compared with adults (Costa et al. 1993). The meaning of those differences remains to be determined.

\section{EFFECTS OF CAPTIVITY}

Captive Egyptian Vultures had significantly higher urate values than did free-living subjects. Plasma urate increased in experimentally fasted Common Buzzards (Buteo buteo) (García-Rodríguez et al. 1987), probably as a result of gluconeogenic catabolism of tissue proteins and delivery of surplus nitrogen to the blood (Cherel et al. 1988). However, urea level also was elevated in raptors fasting either naturally (Ferrer and Dobado-Berrios, in press) or experimentally (García-Rodríguez et al. 1987), probably because gluconeogenesis involves the use of the ubiquitous amino acid arginine (Bell and Freeman 1971). It seems unlikely that captive Egyptian Vultures fed less than their free-living counterparts, given that urea values were similar in both groups. Increasing dietary protein also increased plasma urate concentration in other birds (Sturkie 1986, Jenni-Eiermann and Jenni 1996). Therefore, hyperuricemia of captive Egyptian Vultures seems to reflect a dietary protein content higher than in nature (see Cooper 1978). The increased values of creatinine and albumin that we found in captivity also support this explanation. Creatinine is high in clinically normal birds fed diets high in animal protein (Lewandowski et al. 1986). Plasma albumin may increase when the protein intake exceeds the birds' requirements (Costa et al. 1993) and may serve as a source of amino acids at times of 
subnormal intake (Ivins et al. 1986, Sturkie 1986).

Plasma cholesterol is affected by exogenous cholesterol as well as by endogenous synthesis (Sturkie 1986). Although increased values in captive Egyptian Vultures might indicate higher cholesterol intake than in free-living birds, hypercholesterolemic effects of a high-protein diet in captivity should not be excluded until analysis of cholesterol turnover is undertaken (Yeh and Leveille 1973).

Increasing the dietary protein level does not influence the activities of either AST or ALT in plasma, but food restriction may cause a sharp increase in AST activity and a decrease in ALT activity (Bell and Freeman 1971). Moreover, damage to muscle and muscular dystrophy often result in high plasma activities of AST and ALT (Bell and Freeman 1971). This information leads us to suggest that elevated values of AST (and probably also of ALT, see Table 1) in captive Egyptian Vultures were not a dietary consequence, but rather a reflection of impaired muscle tone associated with their confinement. Elevated calcium and phosphorus concentrations in captive Egyptian Vultures resemble previous observations in caged, exercise-deprived domestic birds with a positive energy balance (Sturkie 1986).

Our results indicate that the profile of plasma chemistries of the Egyptian Vulture was modified largely from nestlings to subadults, and then remained virtually stable in adults. Changes with age in some chemical variables such as urate and AP appear to be in common with those in other wild bird species, whereas other trends do not. Clearly, age-related effects on plasma biochemistry of birds have been largely overlooked, and this factor should be considered in future studies. In addition, many differences were detected between free-living and captive Egyptian Vultures, and even between captive studies, and these differences are attributed to variation in diet quality and physical activity. Other researchers suggested that handling stress (Perry et al. 1986), amount of food ingested (JenniEiermann and Jenni 1994), and feeding pattern (Montesinos et al. 1997) also are potential sources of plasma chemistry variability between free-living and captive conditions. Therefore, care should be taken in using values from captive birds to interpret plasma chemistry of wild subjects.

\section{ACKNOWLEDGMENTS}

We thank D. Campión, I. García-Bello, D. GómezSamitier, R. López, F. Martínez-Olivas, J. A. PérezNievas, A. Sanz, J. Solé, and A. Urmeneta for their assistance with field work. We also are indebted to the staff of the zoos of Madrid and Barcelona and the raptor centers of Lérida and Sevilleja de la Jara. J. Lucientes (Department of Animal Pathology, Veterinary University of Zaragoza) and S. García-Merlo and M. Palacios (Department of Biochemistry, Hospital of Navarra) helped with the blood analyses, and A. Pasick revised the English text. W. D. Koenig and two anonymous reviewers greatly improved the manuscript. The study was partially financed by the Servicio de Medio Ambiente del Gobierno de Navarra.

\section{LITERATURE CITED}

Bell, D. J., And D. M. Freeman. 1971. Physiology and biochemistry of the domestic fowl. Vol. 2. Academic Press, New York.

Cavallo, D., R. De Vita, P. Eleuteri, R.H.R. BelTERMAN, AND G. DELl'OMo. 1997. Sex identification in the Egyptian Vulture by flow cytometry and cytogenetics. Condor 99:829-832.

Ceballos, O., and J. A. Donázar. 1990. Parent-offspring conflict during the post-fledging period in the Egyptian Vulture Neophron percnopterus (Aves, Accipitridae). Ethology 85:225-235.

Chandler, C. R. 1995. Practical considerations in the use of simultaneous inference for multiple tests. Anim. Behav. 49:524-527.

Cherel, Y., J.-P. Robin, AND Y. Le Maho. 1988. Physiology and biochemistry of long-term fasting in birds. Can. J. Zool. 66:159-166.

COOPER, J. E. 1978. Veterinary aspects of captive birds of prey. The Standfast Press, Saul, U.K.

Costa, N. D., D. E. McDonald, ANd R. A. Swan. 1993. Age-related changes in plasma biochemical values of farmed Emus (Dromaius novaehollandiae). Aust. Vet. J. 70:341-344.

Dawson, R. D., And G. R. Bortolotti. 1997. Total plasma protein level as an indicator of condition in wild American Kestrels (Falco sparverius). Can. J. Zool. 75:680-686.

De le Court, C., E. Aguilera, and F. Recio. 1995. Plasma chemistry values of free-living White Spoonbills (Platalea leucorodia). Comp. Biochem. Physiol. 112A:137-141.

Dell'Omo, G., AND R. Cavallina. 1996. Blood chemistry and haematological values of captive Egyptian Vultures (Neophron percnopterus). Avian Pathol. 25:613-618.

Dobado-Berrios, P. M., ANd M. Ferrer. 1997. Agerelated changes of plasma alkaline phosphatase and inorganic phosphorus, and late ossification of the cranial roof in the Spanish Imperial Eagle ( $A q$ uila adalberti C. L. Brehm, 1861). Physiol. Zool. 70:421-427.

DONÁZAR, J. A. 1993. Los buitres ibéricos: biología y conservación. J. M. Reyero, Madrid.

Donázar, J. A., ANd O. Ceballos. 1990. Post-fledgling dependence period and development of flight 
and foraging behaviour in the Egyptian Vulture Neophron percnopterus. Ardea 78:387-394.

FERRER, M. 1993. Blood chemistry studies in birds: some applications to ecological problems, $\mathbf{p}$ 1031-1044. In S. G. Pandali [ed.], Trends in comparative biochemistry and physiology. Council Scientific Res. Integration, Trivandrum, India.

FerRer, M., ANd P. DOBAdo-BerRios. In press. Factors affecting plasma chemistry values of the Spanish Imperial Eagle, Aquila adalberti. Comp. Biochem. Physiol. A.

Ferrer, M., T. García-Rodríguez, J. C. Carrillo, AND J. CASTroviejo. 1987. Hematocrit and blood chemistry values in captive raptors (Gyps fulvus, Buteo buteo, Milvus migrans, Aquila heliaca). Comp. Biochem. Physiol. 87A:1123-1127.

García-Rodríguez, T., M. Ferrer, J. C. Carrillo, AND J. Castroviejo, 1987. Metabolic responses of Buteo buteo to long-term fasting and refeeding. Comp. Biochem. Physiol. 87A:381-386.

GavetT, A. P., AND J. S. WAKeley. 1986. Blood constituents and their relation to diet in urban and rural House Sparrows. Condor 88:279-284.

GonzÁlez, J. L., AND F. Hiraldo. 1991. Some hematological data from Marsh Harriers (Circus aeruginosus) in central Spain. Comp. Biochem. Physiol. 100A:735-737.

Hoffman, D. J., J. C. Franson, O. H. Pattee, C. BunCK, AND H. C. Murray. 1985. Biochemical and hematological effects of lead ingestion in nestling American Kestrels (Falco sparverius). Comp. Biochem. Physiol. 80C:431-439.

Ivins, G. K., G. D. WeddLe, and W. H. Halliwell. 1986. Hematology and serum chemistries in birds of prey, p. 434-437. In M. E. Fowler [ed.], Zoo and wild animal medicine. 2nd ed. W. B. Saunders, Philadelphia, PA.

Jenni-EiermanN, S., AND L. Jenni. 1994. Plasma metabolite levels predict individual body-mass changes in a small long-distance migrant, the Garden Warbler. Auk 111:888-899.

JenNi-EIERManN, S., AND L. JenNI. 1996. Metabolic differences between the postbreeding, moulting and migratory periods in feeding and fasting passerine birds. Funct. Ecol. 10:62-72.

Lewandowski, A. H., T. W. Campbell, and G. J. HaRRISON. 1986. Clinical chemistries, p. 192-200. In G. J. Harrison and L. R. Harrison [eds.], Clinical avian medicine and surgery including aviculture. W. B. Saunders, Philadelphia, PA.

Migliorini, R. H., C. Linder, J. L. Moura, AND J. A. VEIGA. 1973. Gluconeogenesis in a carnivorous bird (Black Vulture). Am. J. Physiol. 225:13891392.

Montesinos, A., A. Sainz, M. V. Pablos, F. MazzucCHElli, AND M. A. Tesouro. 1997. Hematological and plasma biochemical reference intervals in young White Storks. J. Wildl. Dis. 33:405-412.

Perry, M. C., N. H. Obrecht, B. K. Williams, and W. J. KUENZEL. 1986. Blood chemistry and hematocrit of captive and wild Canvasbacks. J. Wildl. Manage. 50:435-441.

Polo, F. J., J. F. Celdrán, V. I. Peinado, G. Viscor, AND J. PALOMEQUE. 1992. Hematological values for four species of birds of prey. Condor 94:10071013.

Polo, F. J., J. Celdrán, G. Viscor, and J. Palomeque. 1994. Blood chemistry of captive herons, egrets, spoonbill, ibis, and gallinule. Comp. Biochem. Physiol. 107A:343-347.

Powers, L. V., M. Pokras, K. Rio, C. Viverette, and L. GoOdRICH. 1994. Hematology and occurrence of hemoparasites in migrating Sharp-shinned Hawks (Accipiter striatus) during fall migration. J. Raptor Res. 28:178-185.

Puerta, M. L., J. C. Alonso, V. Huecas, J. A. AlonSo, M. Abelenda, ANd R. Muñoz-Pulido. 1990 Hematology and blood chemistry of wintering Common Cranes. Condor 92:210-214.

Puerta, M. L., A. L. García del Campo, M. AbelenDa, A. Fernández, V. Huecas, and M. P. Nava. 1992. Hematological trends in Flamingos, Phoenicopterus ruber. Comp. Biochem. Physiol. 102A: 683-686.

REDIG, P. 1991. Medical management of birds of prey. The Raptor Center, Univ. Minnesota, St. Paul, $\mathrm{MN}$.

Sturkie, P. D. 1986. Avian physiology. Springer-Verlag, New York.

Terrasse, M. 1990. Reintroduction du Vautour Fauve dans les Grands causses et reforcement de population du Vautour Percnoptère. Rev. Ecol. (Terre Vie), Suppl. 5:213-225.

Viñuela, J., M. Ferrer, ANd F. Recio. 1991. Agerelated variations in plasma levels of alkaline phosphatase, calcium and inorganic phosphorus in chicks of two species of raptors. Comp. Biochem. Physiol. 99A:49-54.

Wolf, S. H., R. W. Schreiber, L. Kahana, AND J. J. TORRES. 1985. Seasonal, sexual and age-related variation in the blood composition of the Brown Pelican (Pelecanus occidentalis). Comp. Biochem. Physiol. 82A:837-846.

YEH, S.-J.C., AND G. A. LEVEILlE. 1973. Influence of dietary protein level on plasma cholesterol turnover and fecal steroid excretion in the chick. J Nutr. 103:407-410. 